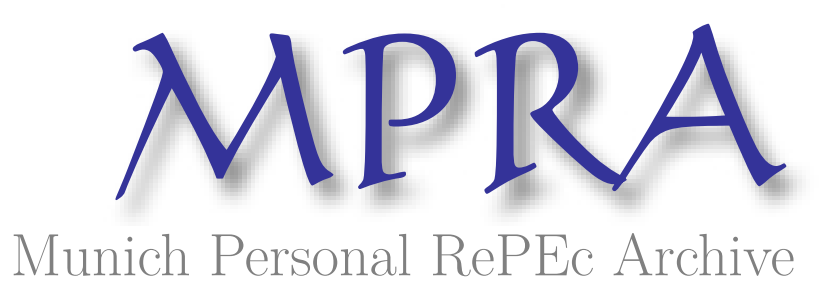

Skills heterogeneity among graduate workers: real and apparent overeducation in the Spanish labor market

Mateos-Romero, Lucía and Salinas Jiménez, María del Mar

Universidad de Extremadura (Spain)

May 2015

Online at https://mpra.ub.uni-muenchen.de/64372/

MPRA Paper No. 64372, posted 08 Jun 2015 14:00 UTC 


\title{
Skills heterogeneity among graduate workers: real and apparent overeducation in the Spanish labor market
}

\author{
Lucía MATEOS-ROMERO (luciamr@unex.es) \\ Universidad de Extremadura \\ María del Mar SALINAS-JIMÉNEZ (msalinas@unex.es) \\ Universidad de Extremadura
}

\begin{abstract}
This paper relaxes the assumption of homogeneous skills among graduate workers and proposes a new approach to differentiate between real and apparent overeducation based on the level of cognitive skills actually achieved by the individuals. This proposal is applied to the study of the wage effects of overeducation in the Spanish labor market using data from PIAAC. The results suggest that between a quarter and a half of the graduate workers who appear to be overeducated in the Spanish labor market could be considered as being only apparently overeducated since they show a lower level of skills than that corresponding to their educational level or, alternatively, a level of cognitive skills which is commensurate with their job. Different returns are found for each group of overeducated individuals both when compared with adequately educated peers within a similar level of education (with greater wage penalties for apparently overeducated workers) and when the comparison is done with wellmatched co-workers doing a similar job (with a wage premium for real overeducation but no significant returns for apparently overeducated workers). These results point to the need of taking account of skills heterogeneity within an educational level when returns to overeducation are analyzed.
\end{abstract}

Key words: educational mismatch; skills heterogeneity; real and apparent overeducation. 


\section{Introduction}

In the last decades, a lot of work on the wage effects of overeducation has been carried out. The empirical evidence suggests that, within a job, overeducated workers tend to receive a wage premium as compared with their properly educated co-workers, although the returns to years of overeducation are lower than those of the education which is actually required for doing their job. On the other hand, when the comparison is made not within a job, but within educational levels, the empirical results point to overeducated workers suffering a wage penalty relative to workers who, with the same educational level, are properly educated for the job they do ${ }^{1}$.

Most of this literature implicitly assumes skills homogeneity among workers within a similar educational level. Hence, when human capital is proxied by attained levels of education, or by years of schooling, it is assumed that individuals within an educational level achieve similar levels of skills. Similarly, when looking at educational mismatch, the educational level of the individual is compared with the requirements of the job, thus assuming that education reflects the skills needed to perform a job. However, there is an increasing dissatisfaction with this hypothesis since workers with similar levels of education might show different levels of skills.

The idea of skills' heterogeneity among workers within a similar level of education has recently led to three main lines of research which aim to address this hypothesis. The first one differentiates between educational and skill mismatches, showing that educational mismatch weakly correlates with skill mismatch (Allen and Van der Velden 2001, Di Pietro and Urwin 2006, Green and McIntosh 2007). The second one uses panel data techniques to control for unobserved heterogeneity (Bauer 2002, Frenette 2004, Lindley and McIntosh 2009). And the last one aims to redefine the idea of overeducation in order to distinguish between real (or genuine) and apparent (or formal)

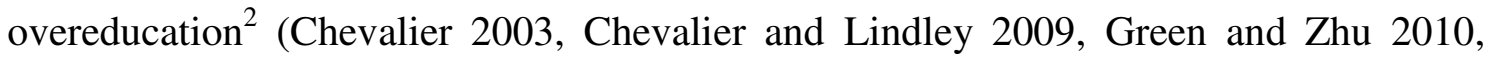
Pecoraro 2014).

\footnotetext{
${ }^{1}$ See Hartog and Oosterbeck (1988) for Holland; Verdugo and Verdugo (1989) for the United States; Dolton and Vignoles (2000) for the United Kingdom; Cohn and Ng (2000) for Hong Kong; or Murillo et al. (2012) for Spain. Extensive reviews on the effects of educational mismatch can be found in Hartog (2000) and Leuven and Oosterbeek (2011).

${ }^{2}$ Whereas Chevalier (2003) distinguishes between 'genuine' and 'apparent' overeducation, other authors such as Green and Zhu (2010) prefer the terms 'real' and 'formal' overeducation. Without going deep into
} 
This work aims to contribute to this literature with a new proposal to differentiate between real and apparent overeducation based on the level of skills actually achieved by overeducated individuals. The idea of skills' heterogeneity involves that some individuals with a higher educational level than that required for their job could in fact show a lower level of skills which actually corresponds to their job's requirements. These overeducated workers could therefore be classified as being only formal or apparently overeducated. Conversely, those overeducated workers who have a level of skills which corresponds to their educational level, that is, a higher level of skills than that required for their job, would be classified as genuine overeducated workers.

Following this idea, some previous studies differentiate between real and apparent overeducation basing on the individuals' satisfaction with the match between their educational level and their job (Chevalier 2003, Chevalier and Lindley 2009) or, alternatively, basing on individuals' self-declared measures of skills mismatch (Green and Zhu 2010, Pecoraro 2014). Both approaches are similar since the satisfaction declared by the individuals with their education-job match could be seen as a proxy of perceived skill mismatch. Under these approaches, overeducated workers who are satisfied with the match between their level of education and the job they hold, or who declare that their skills match the requirements of their jobs, are classified as apparently overeducated workers. On the contrary, those overeducated workers who are not satisfied with the match between their education and the job held, or who declare to suffer a mismatch in skills, are considered as being real or genuine overeducated. While these definitions have the advantage of taking the hypothesis of skills heterogeneity into account, they do not consider the skills actually acquired by the individuals in a straight way, but rather approximate them through individuals' subjective assessments of skill mismatch.

In this work, we propose an alternative approach to define real and apparent overeducation based on the objective level of cognitive skills achieved by the individuals. In order to test the hypothesis of skills heterogeneity among graduate workers, this proposal is then applied to the analysis of the wage effects of overeducation in the Spanish labor market. To this end, we use the PIAAC database, which offers information on the level of cognitive skills acquired by the individuals.

a terminological discussion, in this work we will refer to genuine or real (and apparent or formal) overeducation indistinctly. 
Since only individuals with a higher education degree are considered, workers in our sample would be either adequately educated for their job or overeducated. Among the overeducated, we then distinguish between real and apparently overeducated workers according to their level of cognitive skills and analyze the wage effects associated to each group in order to test whether skills heterogeneity among graduate workers translates into different returns.

The rest of the paper is structured as follows. Section 2 describes the conceptual framework of the approach proposed to distinguish between real and apparent overeducation and discusses its expected effects on wages. Section 3 presents the PIAAC database and the variables used in this study. Section 4 offers the results of the empirical analysis on the effects of (real and apparent) overeducation on wages. Finally, the paper closes with a section where the main conclusions of the study are discussed.

\section{Conceptual framework: Overeducation, skills heterogeneity and wages}

Assuming skills homogeneity when analyzing the effects of overeducation may lead to misleading results since workers with similar levels of education may show very different levels of skills. It is usually considered that overeducation exists when an individual has attained a higher educational level than that which is required to perform his/her job, so overeducation is associated with an excess of education in regard to the job an individual hold. However, if skills acquired by individuals vary within an educational level, this excess of education does not necessarily translate into an excess of skills. So, as pointed by Chevalier (2003), overeducation might come from the lack of skills of graduates.

Considering only individuals with a level of higher education, we would find that most of the graduate workers with a high level of skills obtain a graduate job, thus being classified as adequately educated workers. Other graduate workers, however, will hold undergraduate jobs and would therefore be classified as overeducated since their educational attainment exceeds the requirements of their job. Among these overeducated workers we could still find individuals with a high level of skills, who could be considered as genuinely overeducated, and other less skilled workers who could be seen as only formal or apparently overeducated given that their skills do in fact correspond to the requirements of the undergraduate job that they hold. The extent of 
overeducation would therefore be overestimated if one assumes that there exists skills homogeneity among graduate workers, with part of the overeducated workers being only apparently overeducated given their lower endowments of skills.

What are the wage effects of overeducation? Two main approaches have been followed in the empirical literature to answer this question. The specification proposed by Verdugo and Verdugo (1989) extends the mincerian wage equation introducing dummies for over- and under-education. This specification controls for attained education, so over- and under-educated workers are compared with workers who achieved a similar level of education but who are adequately educated. On the other hand, Duncan and Hoffman (1981) decompose attained education into years of over-, required-, and under-education (ORU specification). Specifications based on the ORU approach control hence for required education, so over- and under-educated workers are compared with adequately educated workers doing a similar job.

Let's restrict these specifications to the specific case of overeducation. When one controls for attained education, the effects of overeducation on individuals' wages can be estimated by an equation of the following form:

$$
\ln \left(w_{i}\right)=\alpha+\beta_{O} O_{i}+\beta_{S} S_{i}+\gamma_{1} E_{i}+\gamma_{2} E_{i}^{2}+\delta X+u_{i}
$$

where $\ln \left(w_{i}\right)$ is the natural logarithm of the hourly wage, $O$ is a dummy variable for overeducated individuals, $S$ is a variable measuring years of attained schooling, $E$ refers to work experience and $X$ is a vector of control variables.

Equation 1 adopts the viewpoint of the individual's educational level in the sense that overeducated workers are compared with adequately educated workers within a similar level of education. From a human capital perspective, workers are rewarded according to their productivity so the job's requirements would not affect wages. In that case, overeducated workers would receive similar returns to education as their peers with a similar educational level who are adequately educated; that is, ceteris paribus, $\beta_{O}$ would be equal to zero $\left(\beta_{O}=0\right)$. A different view of the wage determination process in the labor market emphasizes the role of the job's requirements, assuming that only job characteristics (or both jobs' and individuals' characteristics) determine wages. If this is the case, overeducated workers would suffer a wage penalty as compared to adequately educated workers with a similar educational level since, by definition, overeducated 
individuals hold jobs with lower educational requirements than their adequately educated peers do; in this case, $\beta_{O}$ would be negative $\left(\beta_{O}<0\right)$.

The empirical results clearly point to overeducated workers earning less than their peers who, with a similar level of education, are adequately educated for the job they do. Two main explanations have been offered for this result, suggesting either that overeducated workers underutilize their skills or that they actually possess lower skills. The first explanation lies in the framework of the Assignment theory (Sattinger, 1993), which assumes that productivity, and hence wages, are determined by both individuals' and jobs' characteristics. In this context, not only attained education but also the use of the acquired skills in their jobs determines workers' pay. Overeducated workers are consequently prevented from using part of their skills since they do lower level jobs which act as a limiting factor to their productivity, hence the pay penalty they suffer as compared with their peers holding a job that match their educational level. On the other hand, the second explanation assumes that overeducated workers are in fact less able or possess lower skills than their adequately matched peers, being therefore less productive and receiving a lower pay. This view rests on the hypothesis of heterogeneous skills among individuals within a similar educational level. Despite achieving a similar level of education, individuals may acquire different skills for several reasons (e.g. innate abilities, socio-economic context, quality of schooling...) and those reaching higher skills would be more likely to end up in a job that match their qualification whereas individuals with lower levels of skills would be prone to being overeducated. Under this hypothesis the lower pay of the overeducated workers would come from being less skilled than their adequately educated peers. Furthermore, since overeducated workers might lack the skills required to do a job that match their educational level, or alternatively they could be seen as holding a lower level job that match their lower skills, they could be thought as being only apparently overeducated.

Some recent works have extended equation (1) to take account of possible heterogeneity among overeducated workers, breaking down the overeducation variable into two categories in order to distinguish between real and apparently overeducated workers. This alternative can be expressed as follows:

$$
\ln \left(w_{i}\right)=\alpha+\beta_{R O} R O_{i}+\beta_{A O} A O_{i}+\beta_{S} S_{i}+\gamma_{1} E_{i}+\gamma_{2} E_{i}^{2}+\delta X+u_{i}
$$


where $R O$ is a dummy variable for individuals who are real or genuinely overeducated whereas $A O$ is a dummy for apparently overeducated workers. If the hypothesis of skills heterogeneity holds, one would expect to find different pay penalties for real and apparently overeducated workers. In this case, genuine and apparently overeducated workers are compared with adequately educated workers with a similar level of education. In regard to real overeducated workers, defined as highly skilled workers holding a job with lower requirements, one would expect that the pay penalty falls or vanishes. Real overeducated workers will show similar levels of skills than their peers who are properly matched, so according to the human capital theory, no wage difference will be observed $\left(\beta_{R O}=0\right)$. It could be the case, however, that the lower characteristics of their jobs limit the productivity of these high skilled workers, who will then suffer a pay penalty $\left(\beta_{R O}<0\right)$. As apparently overeducated workers, as defined above, have lower levels of skills than their adequately educated peers they are expected to suffer a pay penalty coming from both their lower skills and the lower job's characteristics $\left(\beta_{A O}<0\right)$. In any case, when comparing real and apparently overeducated workers, the wage penalty of apparently overeducated workers is expected to be greater, given their lower level of skills, than that of the genuine overeducated $\left(\beta_{A O}<\beta_{R O}\right)^{3}$.

Following a different approach, a firm perspective is adopted when one controls for the education required to get a job. The equivalent to equation 1 would be given by:

$$
\ln \left(w_{i}\right)=\alpha+\beta_{O} O_{i}+\beta_{R} R_{i}+\gamma_{1} E_{i}+\gamma_{2} E_{i}^{2}+\delta X+u_{i}
$$

where years of attained schooling ( $S$ in equation 1$)$ are replaced by years of required education ( $R$ in equation 3$)$. When the job's requirements view is adopted, overeducated workers are compared with well-matched workers doing a similar job. Once again, different results will be expected depending on the view of the wage determination process. If only job's characteristics are assumed to determine wages one would expect that overeducated workers earn a similar wage than their appropriately matched colleagues doing a similar job; that is, $\beta_{O}=0$. However, if the individuals' characteristics

\footnotetext{
${ }^{3}$ Previous works testing the hypothesis of heterogeneity among overeducated workers use a similar specification to that of equation (2). However, their definition of the variables of genuine and apparent overeducation bases on self-declared measures of skills (mis)match, either in a direct way (Green and Zhu 2010, Pecoraro 2014) or indirectly through the satisfaction with the education-job match (Chevalier 2003). Since their definition of the variables of interest differs from that followed in this paper, the interpretation of the results might clearly vary. This point will be further addressed when discussing the results in the last section.
} 
also have a role in determining earnings, overeducated workers would be expected to receive a greater wage than their lees educated co-workers who are properly matched, so $\beta_{O}$ will be positive $\left(\beta_{O}>0\right)$.

The empirical literature generally supports this last view since overeducated workers seem to receive a wage premium when compared to properly matched workers within a similar job. What would happen if we consider that overeducated workers are heterogeneous in skills? Similarly to equation (2), the overeducation variable could be decomposed into two variables: real $(R O)$ and apparent overeducation $(A O)$.

$$
\ln \left(w_{i}\right)=\alpha+\beta_{R O} R O_{i}+\beta_{A O} A O_{i}+\beta_{R} R_{i}+\gamma_{1} E_{i}+\gamma_{2} E_{i}^{2}+\delta X+u_{i}
$$

At first, the wage premium of the overeducated workers would be expected to come from their higher skills. Thus, if genuine and apparently overeducated workers are distinct groups in regard to the skills they possess, one would expect the wage premium of the overeducated workers to be driven by the genuine overeducated subset. Since apparently overeducated workers have lower skills than those corresponding to their educational level, they would not be expected to receive a premium for those skills. In other words, as apparently overeducated workers do a job which is commensurate with their skills they are expected to receive a similar wage to that of their adequately matched co-workers $\left(\beta_{A O}=0\right)$. On the other hand, genuine overeducated workers show a higher level of skills than their properly matched colleagues so, if these higher skills are rewarded, genuine overeducated workers would be expected to receive higher wages $\left(\beta_{R O}>0\right)$.

\section{Database and variables}

Data used in this study come from the Programme for the International Assessment of Adult Competencies (PIAAC), a new survey developed by the OECD which provides information about adults aged 16 to 65 . One module provides information on cognitive skills, which were evaluated through standardized tests on a scale from 0 to 500 points ${ }^{4}$. In addition, a background questionnaire offers information about the demographic

\footnotetext{
${ }^{4}$ PIAAC assesses three domains of cognitive skills: literacy, numeracy, and problem solving in technology-rich environments. However, in the case of Spain, only the two first skills were evaluated.
} 
characteristics, education, social background, income or employment status of the individuals.

In the Spanish case, the sample selection was conducted by the Spanish National Institute of Statistics. In this study, this sample is restricted to workers with a level of higher education (ISCED 5-6). In addition, only salaried employees are considered and the maximum wage has been limited to 200 euros per hour (including bonuses) to avoid outliers that could distort the estimates. Observations for which information is not available to define the educational mismatch variables are also dropped from the analysis. As result, the final sample used in the estimations contains 913 observations.

All the estimated specifications take as dependent variable the natural logarithm of the hourly wage (including bonuses) as declared by workers in the background questionnaire. As independent variables, we introduce some variables related to education (years of attained education or years of required education) and years of work experience (and its square), as well as other personal characteristics variables, like gender and nationality, and some labor status related variables (e.g. firm size, supervisory tasks, ownership sector $)^{5}$.

Table 1 offers the descriptive statistics of these variables. The hourly wage ranges from 2.06 to 107.87 euros, being the average hourly wage 14.26 . As only individuals with higher education are considered, the minimum years of attained education are 14 and the maximum rise to 21 , with a mean of 15.63. Average years of required education are lower and stand at 14.14 , thus pointing to some individuals being overeducated; in fact, the minimum years of required education is 6 . Average years of experience stand at 15.64. Males represent $46 \%$ of the sample and $92 \%$ of the individuals were born in Spain. In regard to the labor status variables, most employees work in small or medium firms (57\% and $24 \%$, respectively), $36 \%$ carry out supervisory tasks and $40 \%$ work in the public sector.

Table 1. Descriptive statistics

\begin{tabular}{lcccc}
\hline \multicolumn{1}{c}{ Variable } & Mean & s.d. & min & max \\
\hline Hourly wage & 14.27 & 9.18 & 2.06 & 107.87 \\
Years of attained schooling & 15.63 & 1.50 & 14 & 21 \\
Years of required schooling & 14.14 & 3.00 & 6 & 21 \\
Experience (years) & 16.25 & 9.87 & 0 & 48
\end{tabular}

\footnotetext{
${ }^{5}$ A detailed description of variables used in this study is provided in the Appendix.
} 


\begin{tabular}{lcccc} 
Experience square & 361.52 & 389.67 & 0 & 2,304 \\
Male & 0.46 & 0.50 & 0 & 1 \\
Female & 0.54 & 0.50 & 0 & 1 \\
Spanish & 0.91 & 0.29 & 0 & 1 \\
Immigrant & 0.09 & 0.29 & 0 & 1 \\
Small firm & 0.58 & 0.49 & 0 & 1 \\
Medium firm & 0.23 & 0.42 & 0 & 1 \\
Large firm & 0.19 & 0.36 & 0 & 1 \\
Supervisor & 0.36 & 0.48 & 0 & 1 \\
Public sector & 0.39 & 0.49 & 0 & 1 \\
\hline Source: own elaboration using PIAAC data. Descriptive statistics
\end{tabular}

Source: own elaboration using PIAAC data. Descriptive statistics calculated for 913 observations and using sampling weights.

As only individuals with a level of higher education are considered, educational mismatch in this study refers to overeducation, so workers in the sample will be either adequately educated or overeducated. The three traditional methods proposed in the literature to measure educational mismatch (i.e. objective, subjective, and statistical methods) are used in order to check the robustness of the results ${ }^{6}$. To apply the objective method we based on information provided by the International Labor Organization, which allows one to establish a match between educational levels and occupational groups according to the International Standard Classification of Education (ISCED) and to the International Standard Classification of Occupations (ISCO). Individuals with higher education (ISCED 5-6) would be expected to be in skilled occupations if they were adequately educated for their job (ISCO 1-3), while those in semi-skilled occupations (ISCO 4-8) are classified as overeducated. The subjective method is applied in an indirect way by comparing the years of education attained by an individual (yrsqual in the PIAAC database) with the years he/she declared as required to get the job (yrsget in the PIAAC database); individuals are classified as adequately educated (overeducated) if years of attained education are equal to (greater than) years required to get their job. Finally, the statistical method is used by considering the average years of education for each occupational group as a measure of realized matched, so workers in the range within plus and minus one standard deviation from the mean are considered as adequately educated whereas those with more years of education than one standard deviation above the mean, for their specific occupation, are classified as overeducated.

\footnotetext{
${ }^{6}$ See Hartog (2000) for an extensive review and discussion on the different methods generally used in the literature to measure educational mismatch.
} 
Once the variables of educational mismatch are defined, a distinction is made between real and apparently overeducated workers according to their level of skills. If overeducated workers are heterogeneous in skills, we could think of some overeducated workers as having a lower level of skills than that corresponding to their educational level or, alternatively, as having a level of skills that match the requirements of the undergraduate job they hold; these overeducated workers would be classified as only apparently overeducated workers given their level of cognitive skills. Otherwise, if overeducated workers show a similar level of skills than other graduates who are wellmatched in a qualified occupation or, alternatively, a level of skills that exceed the requirements of their undergraduate job, they will be classified as real or genuine overeducated workers.

\begin{tabular}{|c|c|c|}
\hline & Skilled graduates & Low-skilled graduates \\
\hline $\begin{array}{c}\text { Skilled jobs } \\
\text { (Graduate skills requirements) }\end{array}$ & Matched & \\
\hline $\begin{array}{c}\text { Semi-skilled jobs } \\
\text { (Undergraduate skills requirements) }\end{array}$ & Real overeducation & Apparent overeducation \\
\hline
\end{tabular}

In order to define the variables of real and apparent overeducation, two benchmarks can therefore be considered: the level of skills achieved by graduate workers who are wellmatched, and the skill level corresponding to the undergraduate job held by overeducated individuals. The next section analyzes the effects of overeducation on wages taking account of skill heterogeneity under these two perspectives.

\section{Effects of (real and apparent) overeducation on wages}

\subsection{The individual's educational level perspective}

When the individual's viewpoint is adopted, the level of skills of overeducated workers is compared with that corresponding to their educational level as proxied by the level of skills acquired by other graduate workers who are well-matched for their job. Overeducated workers will then be classified as being real or genuinely overeducated when they have a similar level of skills than their well-matched graduate peers, but hold a job with lower educational requirements. In order to identify genuine overeducated workers we take the mean value of cognitive skills acquired by well-matched graduate peers and then compare the skills of overeducated workers with that mean: if the skills 
of overeducated workers are equal to (or greater than) this mean the workers are classified as genuinely overeducated; otherwise, those overeducated workers with a lower level of skills are classified as being only apparently overeducated.

This procedure has been applied for each traditional method to measure educational mismatch and we have taken the average of the ten plausible values in the domain of literacy skills ${ }^{7}$. The distribution of educational mismatch for each measurement method is offered in Table 2.

Table 2. Educational (mis)match and real and apparent overeducation from the viewpoint of the individuals' educational level

\begin{tabular}{lccc}
\hline & Objective method & Subjective method & Statistical method \\
\hline Well-matched & $64.04 \%$ & $56.81 \%$ & $82.42 \%$ \\
Overeducated & $35.96 \%$ & $43.19 \%$ & $17.58 \%$ \\
Real overeducated & $12.44 \%$ & $20.42 \%$ & $10.53 \%$ \\
Apparent overeducated & $23.52 \%$ & $22.77 \%$ & $7.06 \%$ \\
\hline
\end{tabular}

Source: Own elaboration using PIAAC data.

It is observed that most of the graduate workers are properly educated for the job they do, although the percentage of overeducated workers is quite important and ranges from $18 \%$ (statistical method) to $43 \%$ (subjective method). Among the overeducated workers, it stands out that around half of the graduate workers who hold a job with lower qualification requirements do in fact show a lower level of cognitive skills than that corresponding to their educational level and are therefore classified as being only apparently overeducated (apparent overeducation reaches between $40 \%$-statistical method- and $65 \%$-objective method- of overeducated workers).

In order to check whether this heterogeneity in skills among overeducated workers translates into different effects on wages, various specifications of equations (1) and (2) are estimated. Both equations control for attained education, so overeducated workers are compared with other graduate peers who are adequately educated for the job they do. Table 3 provides the estimation results for each method of measurement of educational mismatch ${ }^{8}$. In each case, the first column corresponds to equation (1),

\footnotetext{
${ }^{7} \mathrm{We}$ also replicated the analysis using numeracy skills. Since literacy and numeracy skills in our sample show a high correlation (0.9381), the obtained results do not change when using one or the other skill domain. Results using the numeracy skill are available upon request.

${ }^{8}$ The Heckman's methodology (Heckman 1979) is used in all estimates to control for possible sample selection bias that could appear as result of wages being observed only for employees. Furthermore, since the PIAAC sample bases on a multistage stratified design, all estimates used the Jackknife2 procedure and sample weights to overcome potential sampling errors.
} 
where traditional measures of overeducation are used, and the second column refers to equation (2), where the overeducation variable is decomposed into real and apparent overeducation.

First we comment on the estimates when the traditional measures of overeducation are used without taking account of skills heterogeneity. The results obtained are consistent with those previously found in the literature. The returns to each additional year of attained schooling vary between $5 \%$ (objective method) and $8 \%$ (subjective and statistical methods), whereas overeducated workers suffer a wage penalty (estimated in the range between $15 \%$ and $23 \%$ ) as compared with their graduate peers who are properly matched. In regard to the control variables, the results are also in accordance with those generally found in the literature (e.g. positive but decreasing effects of experience, and positive wage premiums for men, workers in larger firms, those with supervisory tasks and those working in the public sector), so we do not go here into details.

The estimates for the control variables (including years of schooling) do not change in a significant way when skills heterogeneity is taken into account via the real and apparent overeducation variables. In this case, a wage penalty for both real and apparent overeducation is found, although it is noteworthy that the wage penalty for apparently overeducated doubles (or more) that of real overeducated workers ${ }^{9}$. When the objective method is considered, the wage penalty for apparently overeducated workers reaches $29 \%$ (against $14 \%$ for real overeducated individuals) as compared with their wellmatched graduated peers. Similar results are found with the subjective method, with an estimated wage penalty of $21 \%$ for apparent overeducation against the $9 \%$ estimated for real overeducation. Last, the statistical method also support these estimated differences, with a non-significant wage penalty in the case of real overeducation and a pay penalty close to $32 \%$ for apparently overeducated workers. In sum, these estimates suggest that the effects of real overeducation on wages would be overestimated if one assumes skills homogeneity among overeducated workers.

\footnotetext{
${ }^{9}$ In all cases, the results from the Wald test show that the null hypothesis of equal coefficients between real and apparent overeducation is rejected at the 5\% significance level.
} 
Table 3. Effects of overeducation on wages (viewpoint of the individuals' educational level)

\begin{tabular}{|c|c|c|c|c|c|c|}
\hline & \multicolumn{2}{|c|}{ Objective method } & \multicolumn{2}{|c|}{ Subjective method } & \multicolumn{2}{|c|}{ Statistical method } \\
\hline Overeducation & $\begin{array}{c}-0.232 * * * \\
(0.0356)\end{array}$ & & $\begin{array}{c}-0.152^{* * * *} \\
(0.0301)\end{array}$ & & $\begin{array}{l}-0.153^{* * *} \\
(0.0556)\end{array}$ & \\
\hline $\begin{array}{c}\text { Real } \\
\text { overeducation }\end{array}$ & & $\begin{array}{c}-0.141 * * * \\
(0.0470)\end{array}$ & & $\begin{array}{c}-0.0942 * * * \\
(0.0364)\end{array}$ & & $\begin{array}{l}-0.0328 \\
(0.0629)\end{array}$ \\
\hline $\begin{array}{c}\text { Apparent } \\
\text { overeducation }\end{array}$ & & $\begin{array}{c}-0.292 * * * \\
(0.0427)\end{array}$ & & $\begin{array}{c}-0.211 * * * \\
(0.0398)\end{array}$ & & $\begin{array}{c}-0.318^{* * * *} \\
(0.0559)\end{array}$ \\
\hline $\begin{array}{l}\text { Years of (attained) } \\
\text { schooling }\end{array}$ & $\begin{array}{c}0.0518 * * * \\
(0.00885)\end{array}$ & $\begin{array}{l}0.0505^{* * *} \\
(0.00876)\end{array}$ & $\begin{array}{l}0.0786 * * * \\
(0.00972)\end{array}$ & $\begin{array}{l}0.0761 * * * \\
(0.00951)\end{array}$ & $\begin{array}{c}0.0827 * * * \\
(0.0121)\end{array}$ & $\begin{array}{c}0.0806 * * * \\
(0.0122)\end{array}$ \\
\hline Experience & $\begin{array}{c}0.0341 * * * \\
(0.00974)\end{array}$ & $\begin{array}{c}0.0357 * * * \\
(0.00964)\end{array}$ & $\begin{array}{c}0.0178 * \\
(0.00920)\end{array}$ & $\begin{array}{l}0.0206 * * \\
(0.00959)\end{array}$ & $\begin{array}{l}0.00971 \\
(0.0100)\end{array}$ & $\begin{array}{c}0.0127 \\
(0.0101)\end{array}$ \\
\hline Experience $^{2}$ & $\begin{array}{c}-0.000573^{* *} \\
(0.000231)\end{array}$ & $\begin{array}{l}-0.0006 * * * \\
(0.000229)\end{array}$ & $\begin{array}{l}-0.000212 \\
(0.000228)\end{array}$ & $\begin{array}{l}-0.000265 \\
(0.000236)\end{array}$ & $\begin{array}{c}-1.75 e-05 \\
(0.000250)\end{array}$ & $\begin{array}{c}-8.12 \mathrm{e}-05 \\
(0.000251)\end{array}$ \\
\hline Male & $\begin{array}{c}0.119 * * * \\
(0.0266)\end{array}$ & $\begin{array}{c}0.115^{* * *} \\
(0.0267)\end{array}$ & $\begin{array}{c}0.113 * * * \\
(0.0280)\end{array}$ & $\begin{array}{c}0.108 * * * \\
(0.0286)\end{array}$ & $\begin{array}{c}0.113 * * * \\
(0.0305)\end{array}$ & $\begin{array}{c}0.107 * * * \\
(0.0299)\end{array}$ \\
\hline Immigrant & $\begin{array}{l}-0.0690 \\
(0.0707)\end{array}$ & $\begin{array}{l}-0.0581 \\
(0.0697)\end{array}$ & $\begin{array}{l}-0.0681 \\
(0.0782)\end{array}$ & $\begin{array}{l}-0.0558 \\
(0.0778)\end{array}$ & $\begin{array}{l}-0.0968 \\
(0.0759)\end{array}$ & $\begin{array}{l}-0.0894 \\
(0.0750)\end{array}$ \\
\hline Medium firm & $\begin{array}{l}0.110 * * * \\
(0.0315)\end{array}$ & $\begin{array}{l}0.107 * * * \\
(0.0313)\end{array}$ & $\begin{array}{l}0.116^{* * * *} \\
(0.0394)\end{array}$ & $\begin{array}{l}0.113 * * * \\
(0.0386)\end{array}$ & $\begin{array}{r}0.0887 * * \\
(0.0365)\end{array}$ & $\begin{array}{c}0.0956^{* * * *} \\
(0.0362)\end{array}$ \\
\hline Large firm & $\begin{array}{c}0.154 * * * \\
(0.0446)\end{array}$ & $\begin{array}{c}0.158 * * * \\
(0.0452)\end{array}$ & $\begin{array}{c}0.163 * * * \\
(0.0465)\end{array}$ & $\begin{array}{c}0.164 * * * \\
(0.0460)\end{array}$ & $\begin{array}{c}0.160 * * * \\
(0.0459)\end{array}$ & $\begin{array}{c}0.163 * * * \\
(0.0455)\end{array}$ \\
\hline Supervisor & $\begin{array}{c}0.191 * * * \\
(0.0281)\end{array}$ & $\begin{array}{c}0.189 * * * \\
(0.0274)\end{array}$ & $\begin{array}{c}0.198 * * * \\
(0.0300)\end{array}$ & $\begin{array}{c}0.200 * * * \\
(0.0301)\end{array}$ & $\begin{array}{c}0.219^{* * * *} \\
(0.0308)\end{array}$ & $\begin{array}{c}0.220 * * * \\
(0.0301)\end{array}$ \\
\hline Public sector & $\begin{array}{c}0.129 * * * \\
(0.0360)\end{array}$ & $\begin{array}{c}0.125^{* * * *} \\
(0.0354)\end{array}$ & $\begin{array}{l}0.152 * * * \\
(0.0348)\end{array}$ & $\begin{array}{c}0.151 * * * \\
(0.0345)\end{array}$ & $\begin{array}{c}0.176^{* * * *} \\
(0.0345)\end{array}$ & $\begin{array}{c}0.175^{* * * *} \\
(0.0335)\end{array}$ \\
\hline Lambda & $\begin{array}{l}-0.0994 \\
(0.232)\end{array}$ & $\begin{array}{l}-0.0620 \\
(0.226)\end{array}$ & $\begin{array}{c}-0.469 * * \\
(0.194)\end{array}$ & $\begin{array}{c}-0.400^{* *} \\
(0.202)\end{array}$ & $\begin{array}{c}-0.626^{* * *} \\
(0.193)\end{array}$ & $\begin{array}{c}-0.561^{* * * *} \\
(0.194)\end{array}$ \\
\hline Constant & $\begin{array}{c}1.205 * * * \\
(0.234)\end{array}$ & $\begin{array}{c}1.198^{* * * *} \\
(0.229)\end{array}$ & $\begin{array}{c}0.972 * * * \\
(0.236)\end{array}$ & $\begin{array}{c}0.967 * * * \\
(0.236)\end{array}$ & $\begin{array}{c}0.965 * * * \\
(0.265)\end{array}$ & $\begin{array}{c}0.947 * * * \\
(0.272)\end{array}$ \\
\hline Regions & Yes & Yes & Yes & Yes & Yes & Yes \\
\hline $\begin{array}{c}\text { Obs. } \\
\text { R-squared }\end{array}$ & $\begin{array}{c}876 \\
0.400 \\
\end{array}$ & $\begin{array}{c}876 \\
0.406 \\
\end{array}$ & $\begin{array}{c}852 \\
0.417 \\
\end{array}$ & $\begin{array}{c}852 \\
0.422 \\
\end{array}$ & $\begin{array}{c}836 \\
0.399 \\
\end{array}$ & $\begin{array}{c}836 \\
0.411 \\
\end{array}$ \\
\hline
\end{tabular}

Standard errors in brackets. *** $\mathrm{p}<0.01, * * \mathrm{p}<0.05, * \mathrm{p}<0.1$

Source: PIAAC database. Jackknife2 procedure and PIAAC's sampling weights used in all estimations.

\subsection{The job's requirements perspective}

The second perspective to distinguish between real and apparent overeducation according to the level of skills takes as reference the requirements of the job. Under this view, the skills of the overeducated individuals are compared with those of workers 
who do a similar job but who are properly educated (i.e. well-matched workers in a similar job). Overeducated workers are then classified as being only apparently overeducated if, despite having higher qualifications, they have a similar level of skills than their well-matched co-workers. In order to identify apparently overeducated workers we take the mean value of skills acquired by (undergraduate) well-matched workers in each occupation and then compare the skills of overeducated workers with that mean: if the skills of overeducated workers are equal to (or lower than) this mean the workers are classified as being apparently overeducated; conversely, if overeducated workers show a higher level of skills they are classified as suffering from genuine or real overeducation.

Again, we apply this procedure for each measurement method of educational mismatch and take the average of the ten plausible values of literacy skills. Table 4 offers the distinction between real and apparent overeducation for each measurement method under the viewpoint of skills' job requirements.

Table 4. Educational (mis)match and real and apparent overeducation from the viewpoint of the jobs' requirements

\begin{tabular}{lccc}
\hline & Objective method & Subjective method & Statistical method \\
\hline Well-matched & $64.04 \%$ & $56.81 \%$ & $82.42 \%$ \\
Overeducated & $35.96 \%$ & $43.19 \%$ & $17.58 \%$ \\
Real overeducated & $26.48 \%$ & $34.04 \%$ & $14.59 \%$ \\
Apparent overeducated & $9.48 \%$ & $9.15 \%$ & $2.99 \%$ \\
\hline
\end{tabular}

Source: Own elaboration using PIAAC data.

Since the average skills level of well-matched (undergraduate) workers in semi-skilled occupations is lower than that of well-matched graduate workers in skilled occupations, the percentage of workers who are classified as being genuinely overeducated is logically greater than before. In fact, under this view, around three quarters of the overeducated are classified as suffering from genuine overeducation whereas the percentage of apparent overeducation only reaches between $17 \%$ (statistical method) and $26 \%$ (objective method) of the graduate workers who hold a job with lower educational requirements ${ }^{10}$.

\footnotetext{
${ }^{10}$ Alternatively, we classified overeducated workers into real and apparently overeducated using the interval within one standard deviation from the mean. The percentages of workers classified as real or apparently overeducated changed slightly, but the estimated effects on wages are qualitative and quantitative similar to those reported here (these estimations are available upon request). Since taking the interval within one standard deviation from the mean (or any value between the average of skills of wellmatched graduate workers and that of undergraduates in semiqualified occupations) is a rather arbitrary
} 
Under the job's perspective, equations (3) and (4) are estimated. These equations control for the required education to get a job, so overeducated workers are compared with their well-matched (undergraduate) co-workers in each occupation. Table 5 provides the estimates of the effects of overeducation on wages. As before, the first column offers the estimates using the traditional measures of overeducation (equation 3 ) whereas in the second column the real and apparent overeducation variables are introduced (equation 4).

Again, the obtained results are in line with those found in the existing literature when skills heterogeneity is not considered. In this case, a wage premium is found for overeducated workers as compared with their well-matched colleagues. Since workers are compared within a similar job, this wage premium for overeducated workers comes from the higher human capital (proxied by education) of graduate workers. In particular, the wage premium estimated for graduate individuals working in occupations with lower educational requirements stands between $7 \%$ (objective method) and 19\% (statistical method).

The results change significantly when variables of real and apparent overeducation are introduced. For all methods of educational mismatch measurement, it is observed that the wage premium for genuine overeducated workers is higher than that estimated for overeducated workers when skill heterogeneity is not taken into account, whereas workers with only apparent overeducation do not receive any significant premium. In particular, the wage premium for real overeducation is estimated between $9 \%$ (objective method) and 21\% (statistical method). On the other hand, no wage premium is found for graduate overeducated workers showing a level of skills according to the (lower) requirements of their job, thus suggesting that a higher level of education does not translate into higher wages if it is not accompanied by the acquisition of the cognitive skills which would correspond to that educational level.

Table 5. Effects of overeducation on wages (viewpoint of the job's requirements)

\begin{tabular}{|c|l|l|l|}
\hline & Objective method & Subjective method & Statistical method \\
\hline Overeducation & $0.0719^{*}$ & $0.127 * * *$ & $0.188^{* * *}$ \\
& $(0.0374)$ & $(0.0345)$ & $(0.0567)$
\end{tabular}

choice, we decided to use the mean value as benchmark so the classification between real and apparent overeducation under the individuals' and jobs' perspectives will offer an idea of the lower and upper values of the distribution between real and apparent overeducation. 


\begin{tabular}{|c|c|c|c|c|c|c|}
\hline $\begin{array}{c}\text { Real } \\
\text { overeducation }\end{array}$ & & $\begin{array}{l}0.0895 * * \\
(0.0410)\end{array}$ & & $\begin{array}{r}0.160 * * * \\
(0.0356)\end{array}$ & & $\begin{array}{r}0.209^{* * * *} \\
(0.0601)\end{array}$ \\
\hline $\begin{array}{c}\text { Apparent } \\
\text { overeducation }\end{array}$ & & $\begin{array}{c}0.0204 \\
(0.0603)\end{array}$ & & $\begin{array}{c}0.0239 \\
(0.0586)\end{array}$ & & $\begin{array}{c}0.0959 \\
(0.0839)\end{array}$ \\
\hline $\begin{array}{l}\text { Years of (required) } \\
\text { schooling }\end{array}$ & $\begin{array}{l}0.0407 * * * \\
(0.00515)\end{array}$ & $\begin{array}{l}0.0408^{* * *} \\
(0.00514)\end{array}$ & $\begin{array}{c}0.0476 * * * \\
(0.00708)\end{array}$ & $\begin{array}{c}0.0461 * * * \\
(0.00706)\end{array}$ & $\begin{array}{l}0.0414 * * * \\
(0.00528)\end{array}$ & $\begin{array}{r}0.0414 * * * \\
(0.00526)\end{array}$ \\
\hline Experience & $\begin{array}{c}0.0110 \\
(0.00756)\end{array}$ & $\begin{array}{c}0.0112 \\
(0.00760)\end{array}$ & $\begin{array}{c}0.00877 \\
(0.00693)\end{array}$ & $\begin{array}{c}0.00892 \\
(0.00689)\end{array}$ & $\begin{array}{l}0.0128 * * \\
(0.00648)\end{array}$ & $\begin{array}{l}0.0131 * * \\
(0.00648)\end{array}$ \\
\hline Experience $^{2}$ & $\begin{array}{l}-0.000118 \\
(0.000168)\end{array}$ & $\begin{array}{l}-0.000120 \\
(0.000169)\end{array}$ & $\begin{array}{l}-0.000107 \\
(0.000158)\end{array}$ & $\begin{array}{l}-0.000101 \\
(0.000157)\end{array}$ & $\begin{array}{l}-0.000152 \\
(0.000138)\end{array}$ & $\begin{array}{l}-0.000155 \\
(0.000138)\end{array}$ \\
\hline Male & $\begin{array}{l}0.153^{* * *} \\
(0.0275)\end{array}$ & $\begin{array}{l}0.152^{* * * *} \\
(0.0278)\end{array}$ & $\begin{array}{l}0.153^{* * * *} \\
(0.0344)\end{array}$ & $\begin{array}{r}0.147^{* * *} \\
(0.0348)\end{array}$ & $\begin{array}{c}0.101 * * * \\
(0.0289)\end{array}$ & $\begin{array}{c}0.0984 * * * \\
(0.0295)\end{array}$ \\
\hline Immigrant & $\begin{array}{c}-0.0915^{* *} \\
(0.0428)\end{array}$ & $\begin{array}{l}-0.0857^{*} \\
(0.0442)\end{array}$ & $\begin{array}{c}-0.000619 \\
(0.0637)\end{array}$ & $\begin{array}{c}0.0171 \\
(0.0641)\end{array}$ & $\begin{array}{c}-0.0897 * * \\
(0.0417)\end{array}$ & $\begin{array}{c}-0.0869^{* *} \\
(0.0419)\end{array}$ \\
\hline Medium firm & $\begin{array}{l}0.133^{* * *} \\
(0.0295)\end{array}$ & $\begin{array}{l}0.134^{* * * *} \\
(0.0296)\end{array}$ & $\begin{array}{l}0.160^{* * *} \\
(0.0444)\end{array}$ & $\begin{array}{r}0.160^{* * *} \\
(0.0438)\end{array}$ & $\begin{array}{c}0.147 * * * \\
(0.0418)\end{array}$ & $\begin{array}{r}0.147 * * * \\
(0.0422)\end{array}$ \\
\hline Large firm & $\begin{array}{l}0.248 * * * \\
(0.0440)\end{array}$ & $\begin{array}{l}0.247 * * * \\
(0.0437)\end{array}$ & $\begin{array}{c}0.164^{* * * *} \\
(0.0395)\end{array}$ & $\begin{array}{c}0.164 * * * \\
(0.0400)\end{array}$ & $\begin{array}{c}0.241^{* * * *} \\
(0.0586)\end{array}$ & $\begin{array}{r}0.241 * * * \\
(0.0584)\end{array}$ \\
\hline Supervisor & $\begin{array}{l}0.137 * * * \\
(0.0345)\end{array}$ & $\begin{array}{l}0.137 * * * \\
(0.0344)\end{array}$ & $\begin{array}{l}0.235^{* * * *} \\
(0.0369)\end{array}$ & $\begin{array}{r}0.236^{* * *} \\
(0.0370)\end{array}$ & $\begin{array}{c}0.104 * * * \\
(0.0361)\end{array}$ & $\begin{array}{r}0.104 * * * \\
(0.0361)\end{array}$ \\
\hline Public sector & $\begin{array}{l}0.202 * * * \\
(0.0372)\end{array}$ & $\begin{array}{l}0.197 * * * \\
(0.0369)\end{array}$ & $\begin{array}{l}0.202^{* * * *} \\
(0.0336)\end{array}$ & $\begin{array}{r}0.199^{* * *} \\
(0.0335)\end{array}$ & $\begin{array}{c}0.167 * * * \\
(0.0395)\end{array}$ & $\begin{array}{r}0.165^{* * *} \\
(0.0396)\end{array}$ \\
\hline Lambda & $\begin{array}{c}0.103 \\
(0.169)\end{array}$ & $\begin{array}{c}0.105 \\
(0.169)\end{array}$ & $\begin{array}{c}-0.257^{* *} \\
(0.128)\end{array}$ & $\begin{array}{l}-0.237^{*} \\
(0.124)\end{array}$ & $\begin{array}{l}-0.0181 \\
(0.123)\end{array}$ & $\begin{array}{l}-0.0127 \\
(0.124)\end{array}$ \\
\hline Constant & $\begin{array}{c}1.201 * * * \\
(0.150)\end{array}$ & $\begin{array}{c}1.197 * * * \\
(0.151)\end{array}$ & $\begin{array}{c}1.300 * * * \\
(0.158)\end{array}$ & $\begin{array}{c}1.305 * * * \\
(0.157)\end{array}$ & $\begin{array}{c}1.293 * * * \\
(0.121)\end{array}$ & $\begin{array}{c}1.288 * * * \\
(0.120)\end{array}$ \\
\hline Regions & Yes & Yes & Yes & Yes & Yes & Yes \\
\hline $\begin{array}{c}\text { Obs. } \\
\text { R-squared }\end{array}$ & $\begin{array}{l}1,001 \\
0.343\end{array}$ & $\begin{array}{l}1,001 \\
0.344\end{array}$ & $\begin{array}{c}747 \\
0.404\end{array}$ & $\begin{array}{c}747 \\
0.410\end{array}$ & $\begin{array}{c}906 \\
0.409\end{array}$ & $\begin{array}{c}906 \\
0.410\end{array}$ \\
\hline
\end{tabular}

Standard errors in brackets. $* * * \mathrm{p}<0.01, * * \mathrm{p}<0.05, * \mathrm{p}<0.1$

Source: PIAAC database. Jackknife2 procedure and PIAAC's sampling weights used in all estimations.

\section{Discussion and concluding remarks}

In this work, the assumption of homogeneous skills among individuals with a similar level of education has been relaxed. Over the last decade, some researchers have suggested new ways to measure educational mismatch with the aim to consider the existence of heterogeneous workers, being the self-declared satisfaction by the individuals in regard to their education-job match, as proposed by Chevalier (2003), or the individuals' perceptions about their (mis)match in skills, as proposed by Green and Zhu (2010), two of the most commonly ways used to distinguish between genuine and 
apparently overeducated workers. In this study, we proposed an alternative approach based on the level of cognitive skills actually achieved by the individuals with a similar level of education.

We used the PIAAC database, which offers information on the cognitive skills of the individuals, and applied this proposal to the study of the wage effects of overeducation in the Spanish labor market by taking account of skills heterogeneity among individuals with a higher education degree. The obtained results are consistent with the conceptual framework and are robust to the use of different measures of educational mismatch. Moreover, two perspectives have been adopted to differentiate between real and apparent overeducation and to analyze the effects of (real and apparent) overeducation on wages: the first one adopting the viewpoint of the individual's educational attainment, and the second one under the perspective of the job's requirements.

Under the individual's educational level perspective, the skills acquired by the overeducated workers are compared with those of their peers who, with the same level of education, are well-matched for the job they do. Overeducated individuals are then classified as suffering real or genuine overeducation if they show a similar level of skills than their well-matched graduate peers, whereas those who have a lower level of skills than what corresponds to their educational degree are classified as being only apparently overeducated. Under this perspective, it is found that around half of the overeducated workers with a higher degree in the Spanish labor market could in fact be classified as only being apparently overeducated. Beyond the distinction between real and apparent overeducation, we analyzed the wage penalties associated with each group of overeducated workers in order to test whether this heterogeneity in skills translates into different returns to education. Both real and apparently overeducated workers suffer a wage penalty as compared with their well-matched graduate peers. However, the wage penalty suffered by real overeducated workers is lower than that of apparent overeducation. Since genuine overeducated workers have a similar level of skills than their well-matched peers, their wage penalty does not come from their lower human capital (as proxied either by their educational level or by their cognitive skills) but from the lower requirements of the job they hold, what can prevent real overeducated workers to fully utilize their skills. In the case of apparent overeducation, a greater wage penalty is estimated, a result which would respond to both holding a job with lower educational 
requirements and having a lower level of skills than what corresponds to their educational level.

Our results differ from those found in previous studies which differentiate between genuine and apparent overeducation, such as those by Chevalier (2003), Green and Zhu (2010) or Pecoraro (2014). In these studies, the wage penalty found for genuine overeducation is greater than that suffered by apparently overeducated workers. This is not in conflict with our results, however, since it arises from the different ways adopted to define real and apparent overeducation. Following Chevalier (2003), genuine overeducated workers are those who, in addition to be overeducated, are not satisfied with the match between their education and the job they hold; it would then be expected that these workers suffer a double pay penalty for, on the one hand, holding a job with lower educational requirements and, on the other, for being dissatisfied with their education-job match. Similarly, Green and Zhu (2010) and Pecoraro (2014) consider those overeducated workers who also declare to suffer an excess of skills as being genuine overeducated, hence the greater wage penalty they suffer since they are mismatched in both education and skills. These results support the hypothesis of heterogeneous workers among the overeducated, but the distinction of real and apparent overeducation based on individuals' perceptions of skill mismatch (or based on the satisfaction with the education-job match) does not allow to directly assess the hypothesis of skills heterogeneity among individuals with a similar level of education. Both Chevalier (2003) and Green and Zhu (2010) find that most of the individuals classified as genuine overeducated according to their definitions do indeed hold jobs with very low requirements, so it could be that this heterogeneity in occupations, and not in skills, gives rise to the greater wage penalties observed for genuine overeducated workers. In fact, overeducated individuals with a lower level of skills than that corresponding to their educational level could be classified, according to these definitions, as being genuine overeducated if they hold a very low-level job. According to the proposal of this study, these workers would be however classified as being only apparently overeducated since they do not have the skills corresponding to their educational level and, consequently, they do not fit the requirements of a graduate job. The differences in the obtained results are therefore not in conflict, but come from the different views adopted to define real and apparent overeducation. 
Our approach directly assesses the hypothesis of skills heterogeneity and also allows one to take account of heterogeneity in occupations when the job's requirement perspective is adopted. Under this view, the skills achieved by overeducated workers are compared with those of their well-matched co-workers within each occupation, so overeducated workers are classified as being only apparently overeducated if, despite their higher educational level, they have a similar level of skills as their well-matched colleagues in each occupation. When the comparison is made within a similar job, it is found that the wage premium get by overeducated workers as compared with their adequately educated co-workers comes from the higher human capital, as measured by the level of cognitive skills, of the subset of genuine overeducated workers. Apparent overeducated workers, on the contrary, do not receive any significant wage premium in spite of their higher level of education since their skills are commensurate with the job they do. This result suggests that holding a higher degree does not translate into higher wages if not accompanied by the acquisition of the corresponding cognitive skills.

The data used in this study prevent us to explore the causes of skills heterogeneity among graduate workers (e.g. innate abilities, motivation, schooling quality, socioeconomic background, etc.), but evidence the need to take the cognitive skills actually acquired by overeducated individuals into account when analyzing the wage effects of overeducation. The distinction between real and apparent overeducation according to the level of cognitive skills achieved by the overeducated workers allows us to disentangle the mechanisms behind the lower pay of overeducated workers as compared with their well-matched graduated peers (or alternatively the wage premium received as compared with their adequately educated co-workers) and suggests that the wage effects of overeducation would be overestimated if homogeneous skills were considered.

\section{References}

- Allen, J. \& Van der Velden, R. (2001): Educational mismatches versus skill mismatches: effects on wages, job satisfaction, and on-the-job search. Oxford Economic Papers 53(3): 434-452.

- Bauer, T. (2002): Educational mismatch and wages: a panel analysis. Economic of Education Review 21(3): 221-229.

- Chevalier, A. (2003): Measuring Over-Education. Economica 70(279): 509-531. 
- Chevalier, A. \& Lindley, J. (2009): Overeducation and the skills of UK graduates. Journal of the Royal Statistical Society: Series A (Statistics in Society) 172(2): 307-337.

- Cohn, E. \& Ng, Y.C. (2000): Incidence and wage effects of overschooling and underschooling in Hong Kong. Economics of Education Review 19(2): 159-168.

- Di Pietro, G. \& Urwin, P. (2006): Education and Skills Mismatch in the Italian Graduate Labor Market. Applied Economics 38(1): 79-93.

- Dolton, P. \& Vignoles, A. (2000): The incidence and the effects of overeducation in the UK graduate labour market. Economics of Education Review 19(2): 179-198.

- Duncan, G. \& Hoffman, S.D. (1981): The Incidence and Wage Effects of Overeducation. Economics of Education Review 1(1): 75-86.

- Green, F. \& McIntosh, S. (2007): Is there a genuine under-utilization of skills amongst the over-qualified?. Applied Economics 39(4): 427-439.

- Green, F. \& Zhu, Y. (2010): Overqualification, job dissatisfaction, and increasing dispersion in the returns to graduate education. Oxford Economic Papers 62(4): 740763.

- Frenette (2004): The overqualified Canadian graduate: the role of the academic program in the incidence, persistence, and economic returns to overqualification. Economics of Education Review 23(1): 29-45.

- Hartog, J. (2000): Over-education and Earnings: Where are We, Where Should We Go? Economics of Education Review 19(2): 131-147.

- Hartog, J. \& Oosterbeek, H. (1988): Education, allocation and earnings in the Netherlands: Overschooling? Economics of Education Review 7(2): 185-194.

- Heckman, J.J. (1979): Sample Selection Bias as a Specification Error. Econometrica 47(1): 53-161.

- Leuven, E. \& Oosterbeek, H. (2011): Overeducation and mismatch in the labor market. Handbook of the Economics of Education 4: 283-326.

- Lindley \& McIntosh (2009): A panel data analysis of the incidence and impact of overeducation. Department of Economics, University of Sheffield, ISNN 1749-8368.

- Murillo, I.P., Rahona, M. \& Salinas, M.M. (2012): Effects of educational mismatch on private returns to education: An analysis of the Spanish case (1995-2006). Journal of Policy Modeling 34(5): 646-659.

- Pecoraro, M. (2014): Is there still a wage penalty for being overeducated but wellmatched in skills? A panel data analysis of a Swiss graduate cohort. Labour 28(3): 309-337.

- Sattinger, M. (1993): Assignment models of the distribution of earnings. Journal of Economic Literature 31: 831-880. 
- Verdugo, R.R. \& Verdugo, N.T. (1989): The impact of surplus schooling on earnings: Some additional findings. Journal of Human Resources 24(4): 629-643. 


\section{Appendix}

Table A.1. Variables definition

\begin{tabular}{|c|c|}
\hline Variable & Definition \\
\hline Wage & $\begin{array}{l}\text { Natural logarithm of hourly wage (including bonuses) } \\
\text { Obtained from earnhrbonus }\end{array}$ \\
\hline Overeducation & $\begin{array}{l}\text { Dummy if the individual is overeducated } \\
0=\text { adequately educated (well-matched) } \\
1=\text { overeducated }\end{array}$ \\
\hline Real overeducation & $\begin{array}{l}\text { Dummy if the individual is really overeducated } \\
0=\text { other } \\
1=\text { really overeducated }\end{array}$ \\
\hline Apparent overeducation & $\begin{array}{l}\text { Dummy if the individual is apparently overeducated } \\
0=\text { other } \\
1=\text { apparently overeducated }\end{array}$ \\
\hline Years of attained schooling & $\begin{array}{l}\text { Years of attained schooling } \\
\text { Obtained from yrsqual }\end{array}$ \\
\hline Years of required schooling & $\begin{array}{l}\text { Years of required schooling to get a job } \\
\text { Obtained from yrsget }\end{array}$ \\
\hline Experience & $\begin{array}{l}\text { Years in a paid job } \\
\text { Obtained from } c_{-} q 09\end{array}$ \\
\hline Gender & $\begin{array}{l}\text { Dummy for individuals' gender } \\
0=\text { female } \\
1=\text { male } \\
\text { Obtained from gender_r }\end{array}$ \\
\hline Nationality & $\begin{array}{l}\text { Dummy for nationality } \\
0=\text { Spanish } \\
1=\text { immigrant } \\
\text { Obtained from } j \_q 04 a\end{array}$ \\
\hline Firm size & $\begin{array}{l}\text { Dummies for firm size } \\
\text { Small: between } 1 \text { and } 50 \text { workers (reference variable) } \\
\text { Medium: between } 51 \text { and } 250 \text { workers } \\
\text { Large: more than } 251 \text { workers } \\
\text { Obtained from } d \_q 06 a\end{array}$ \\
\hline Supervisor & $\begin{array}{l}\text { Dummy if the individual does supervisory tasks } \\
0=\text { no supervisor } \\
1=\text { supervisor } \\
\text { Obtained from } d \_q 08 a\end{array}$ \\
\hline Sector & $\begin{array}{l}\text { Dummy if the individual works in the public sector } \\
0=\text { other } \\
1=\text { public sector } \\
\text { Obtained from } d \_q 0\end{array}$ \\
\hline Regions & Dummy for each region (17 Autonomous Communities) \\
\hline
\end{tabular}

